Article

\title{
Chaetomadrasins A and B, Two New Cytotoxic Cytochalasans from Desert Soil-Derived Fungus Chaetomium madrasense 375
}

\author{
Qing-Feng Guo ${ }^{1}$, Zhen-Hua Yin ${ }^{1}$, Juan-Juan Zhang ${ }^{1}$, Wen-Yi Kang ${ }^{1}{ }^{\circledR}$, Xue-Wei Wang ${ }^{2}$, \\ Gang Ding ${ }^{3, *}$ and Lin Chen ${ }^{1, *}$ \\ 1 Henan Joint International Research Laboratory of Drug Discovery of Small Molecules, Zhengzhou Key \\ Laboratory of Synthetic Biology of Natural Products, Huanghe Science and Technology College, \\ Zhengzhou 450063, Henan, China \\ 2 Institute of Microbiology, Chinese Academy of Science, Beijing 100101, China \\ 3 Institute of Medicinal Plant Development, Chinese Academy of Medical Science and Union Medical College, \\ Beijing 100193, China \\ * Correspondence: gding@implad.ac.cn (G.D.); lchenchina@163.com (L.C.); Tel.: +86-371-8754-0859 (L.C.)
}

Academic Editors: Juan Francisco Leon and Paula B. Andrade

Received: 8 July 2019; Accepted: 3 September 2019; Published: 5 September 2019

check for updates

\begin{abstract}
Two new cytochalasans, Chaetomadrasins A (1) and B (2), along with six known analogues (3-8), were isolated from the solid-state fermented culture of desert soil-derived Chaetomium madrasense 375. Their structures were clarified by comprehensive spectroscopic analyses, and the absolute configurations of Compounds 1 and 2 were confirmed by electronic circular dichroism (ECD) and calculated ECD. For the first time, Chaetomadrasins A (1), which belongs to the chaetoglobosin family, is characterized by the presence of all oxygen atoms in the form of Carbonyl. Chaetomadrasin B (2) represents the first example of chaetoglobosin type cytochalasan characterized by a hydroxy unit and carbonyl group fused to the indole ring. Compounds $\mathbf{1}$ and $\mathbf{2}$ displayed moderate cytotoxicity against HepG2 human hepatocellular carcinoma cells.
\end{abstract}

Keywords: Chaetomium madrasense; cytochalasans; cytotoxicity; fungal alkaloids

\section{Introduction}

Cytochalasans are a well-known class of alkaloids characterized by a perhydroisoindolone moiety, to which a typical macrocyclic ring is fused [1]. These fungal alkaloids are characterized by a polyketide backbone and an amino acid (such as leucine, tryptophan or phenylalanine) with a broad spectrum of bioactivity, including cytotoxic [2-4], antibacterial [5], phytotoxic [6], antiviral [7], and immunomodulatory activities [8,9]. Cytochalasans caught chemists' and pharmacologists' attention because of their complex polycyclic fused skeletons and interesting biological activities. Numerous bioactive cytochalasans with novel skeletons have been reported in recent years [10-13], and, to date, more than 300 cytochalasans or analogues have been reported from diverse fungal genera, including Chaetomium, Aspergillus, Trichoderma, and Periconia [12-15].

In our continued discovery of bioactive natural products from the members of special fungi isolated from the desert and grasslands inhabiting the Northwest of China [16-19], two new cytochalasan derivatives, Chaetomadrasins A (1) and B (2), together with six related known compounds (3-8) (Figure 1), were isolated and identified from the ethyl acetate extract of a solid-state fermented culture of Chaetomium madrasense 375, which was collected from desert soil in Hotan city, Sinkiang province, People's Republic of China. However, as far as we know, this is the first report on secondary metabolites from the fungi. Chaetomadrasins A (1) and B (2) were evaluated in vitro for their cytotoxicities against 
the HepG-2 cell line, with cis-platin as a positive control. Herein, we present the isolation, structural elucidation, and bioactivity of these compounds.

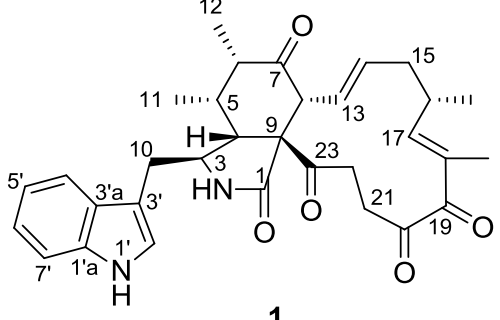

1

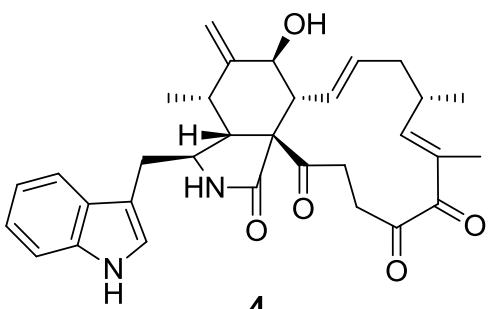

4

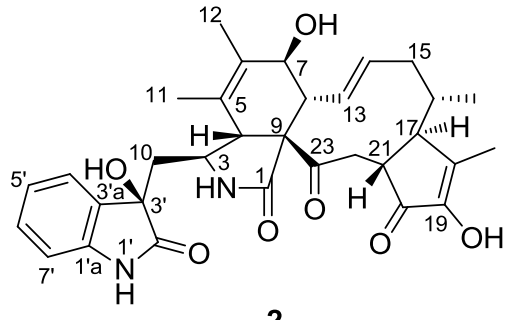

2

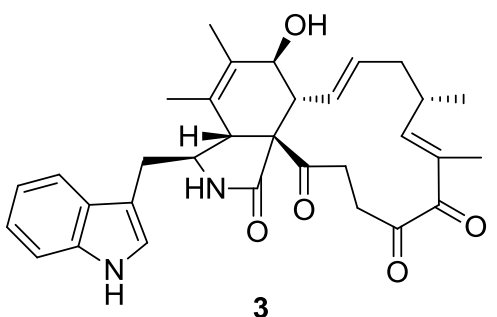

3

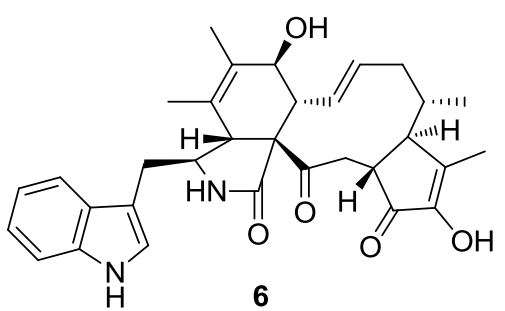

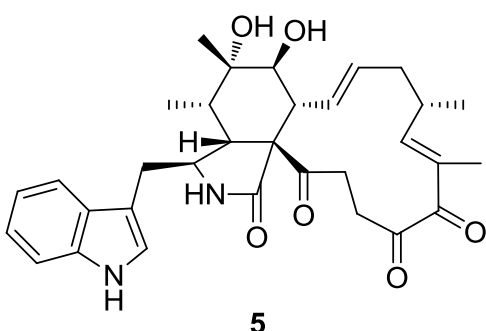

5

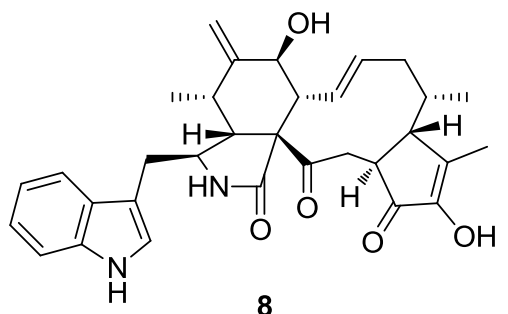

Figure 1. Structures of isolated Compounds 1-8.

\section{Results and Discussion}

Chaetomadrasin A (1) was isolated as a white amorphous powder. The HR-ESI-MS data suggested a molecular formula of $\mathrm{C}_{32} \mathrm{H}_{36} \mathrm{~N}_{2} \mathrm{O}_{5}$ based on the $[\mathrm{M}+\mathrm{Na}]^{+}$ion signal at 551.2518. The IR spectrum showed absorption bands at 3370 and $1714 \mathrm{~cm}^{-1}$, thereby implying the presence of amino and carbonyl groups. The aromatic protons signals at $\delta_{\mathrm{H}} 7.51\left(\mathrm{~d}, 7.0, \mathrm{H}-4^{\prime}\right), 7.15\left(\mathrm{t}, 7.4, \mathrm{H}-5^{\prime}\right), 7.22\left(\mathrm{t}, 7.5, \mathrm{H}-6^{\prime}\right)$, and $7.36\left(\mathrm{~d}, 8.0, \mathrm{H}-7^{\prime}\right)$, along with an olefinic proton at $\delta_{\mathrm{H}} 7.09\left(\mathrm{~s}, \mathrm{H}-2^{\prime}\right)$ and a broad NH singlet at $\delta_{\mathrm{H}} 8.71$ $\left(\mathrm{H}-1^{\prime}\right)$, could be assigned to a 3-substituted indolyl group. The ${ }^{1} \mathrm{H},{ }^{13} \mathrm{C}$ (Table 1), and HSQC (Figure S4) nuclear magnetic resonance (NMR) spectral data for $\mathbf{1}$ revealed the presence of four methyl groups, four methylene units, six methine units, one quaternary carbon, 12 olefinic and aromatic carbons, and five carbonyl carbons, which were quite similar to those of chaetoglobosin Y [20]. The main differences between the two compounds are at positions C-20, with the hydroxy substituent (C-20) in chaetoglobosin $\mathrm{Y}$ being replaced by the carbonyl group on $\mathrm{C}-20$ in Compound 1 . This conclusion is further supported by the chemical shifts of $C-20\left(\delta_{C} 204.8\right)$ and the ${ }^{1} \mathrm{H}$ detected heteronuclear multiple bond correlation (HMBC) (Figure S5) cross-peaks from H-21 to C-20. Further evidence for the structure of 1 was provided by its $\mathrm{HMBC}$ and ${ }^{1} \mathrm{H}-{ }^{1} \mathrm{H}$ correlation spectroscopy (COSY) spectra (Figure 2). In this way, the planar structure of $\mathbf{1}$ was characterized. The relative configuration of $\mathbf{1}$ was established by nuclear overhauser enhancement spectroscopy (NOESY) experiment. In the perhydro-isoindolone ring, the NOESY (Supplementary Figure S6, Figure 3) correlations of 11-Me/H-3, H-4/H-8, H-4/H-10a, $\mathrm{H}-5 / \mathrm{H}-8$, and $\mathrm{H}-6 / \mathrm{H}-8$ implied that $\mathrm{H}-3,11-\mathrm{Me}$, and 12-Me are $\alpha$-oriented, while $\mathrm{H}-4, \mathrm{H}-5, \mathrm{H}-6$, and $\mathrm{H}-8$ are $\beta$-oriented. Furthermore, NOESY correlations from $\mathrm{H}-14$ to $\mathrm{H}-8$ and $\mathrm{H}-16$ suggested that $\mathrm{H}-14$, $\mathrm{H}-8$ and $\mathrm{H}-16$ were cofacial and $\beta$-oriented. Furthermore, the large coupling constant of $\mathrm{H}-8 / \mathrm{H}-13$ $\left(J_{8,3}=15.1 \mathrm{~Hz}\right)$ suggested that $\mathrm{H}-13$ should be $\alpha$-oriented . 
Table 1. ${ }^{13} \mathrm{C}(100 \mathrm{MHz})$ and ${ }^{1} \mathrm{H}(400 \mathrm{MHz})$ NMR spectroscopic data for Compounds 1 and 2.

\begin{tabular}{|c|c|c|c|c|}
\hline \multirow{2}{*}{ NO. } & \multicolumn{2}{|l|}{$1^{a}$} & \multicolumn{2}{|l|}{$2^{b}$} \\
\hline & $\delta_{\mathrm{H}}$, mult. $(J$ in $\mathrm{Hz})$ & $\delta_{\mathrm{C}}$, mult. & $\delta_{\mathrm{H}}$, mult. $(J$ in $\mathrm{Hz})$ & $\delta_{\mathrm{C}}$, mult. \\
\hline $1^{\prime}$ & $8.71, \mathrm{~s}$ & & $10.3, \mathrm{~s}$ & \\
\hline $1^{\prime} \mathrm{a}$ & & 136.1, C & & 142.3, C \\
\hline $2^{\prime}$ & $7.09, \mathrm{~s}$ & $124.6, \mathrm{CH}$ & $6.96, \mathrm{~s}$ & $178.8, \mathrm{CH}$ \\
\hline $3^{\prime}$ & & $109.2, \mathrm{C}$ & & 74.6 \\
\hline $3^{\prime} \mathrm{a}$ & & $127.5, \mathrm{C}$ & & 131.6 \\
\hline $4^{\prime}$ & $7.51, \mathrm{~d}(7.0)$ & $118.2, \mathrm{CH}$ & $7.22, \mathrm{~d}(7.2)$ & $124.7, \mathrm{CH}$ \\
\hline $5^{\prime}$ & $7.15, \mathrm{t}(7.4)$ & $120.2, \mathrm{CH}$ & $7.00, \mathrm{t}(7.4)$ & $122.1, \mathrm{CH}$ \\
\hline $6^{\prime}$ & $7.22, \mathrm{t}(7.5)$ & $122.6, \mathrm{CH}$ & $7.23, \mathrm{t}(7.0)$ & $129.8, \mathrm{CH}$ \\
\hline $7^{\prime}$ & $7.36, \mathrm{~d}(8.0)$ & $111.6, \mathrm{CH}$ & $6.82, \mathrm{~d}(8.0)$ & $110.6, \mathrm{CH}$ \\
\hline 1 & & $174.1, \mathrm{C}$ & & $174.5, \mathrm{C}$ \\
\hline 2 & $7.52, \mathrm{~s}$ & & $7.74, \mathrm{~s}$ & \\
\hline 3 & $3.86, \mathrm{~m}$ & $52.6, \mathrm{CH}$ & $3.16, \mathrm{~m}$ & $52.3, \mathrm{CH}$ \\
\hline 4 & $2.42, \mathrm{~m}$ & $46.9, \mathrm{CH}$ & $2.80, \mathrm{~s}$ & $51.6, \mathrm{CH}$ \\
\hline 5 & $2.23, \mathrm{~m}$ & $35.4, \mathrm{CH}$ & & $125.9, \mathrm{C}$ \\
\hline 6 & $2.14, \mathrm{~m}$ & $46.1, \mathrm{CH}$ & & $134.5, \mathrm{C}$ \\
\hline 7 & & 213.4, C & $3.79, \mathrm{~d}(8.7)$ & $68.9, \mathrm{CH}$ \\
\hline 8 & $3.84, \mathrm{~d}(9.4)$ & $53.0, \mathrm{CH}$ & $2.07, \mathrm{~m}$ & $52.9, \mathrm{CH}$ \\
\hline 9 & & $62.9, \mathrm{C}$ & & $65.5, \mathrm{C}$ \\
\hline 10 & a: $3.15, \mathrm{~m} ; \mathrm{b}: 2.83, \mathrm{~m}$ & 32.6, $\mathrm{CH}_{2}$ & $\mathrm{a}: 1.80, \mathrm{~m} ; \mathrm{b}: 1.73, \mathrm{~m}$ & $43.8, \mathrm{CH}_{2}$ \\
\hline 11 & $1.20, \mathrm{~d}(6.4)$ & $15.9, \mathrm{CH}_{3}$ & $1.32, \mathrm{~s}$ & $16.9, \mathrm{CH}_{3}$ \\
\hline 12 & $1.16, \mathrm{~d}(6.8)$ & $15.9, \mathrm{CH}_{3}$ & $1.54, \mathrm{~s}$ & $15.0, \mathrm{CH}_{3}$ \\
\hline 13 & 5.85, dd $(15.1,9.5)$ & $122.9, \mathrm{CH}$ & $6.03,(15.4,9.8)$ & $131.4, \mathrm{CH}$ \\
\hline 14 & $5.00, \mathrm{~m}$ & $135.5, \mathrm{CH}$ & $5.05, \mathrm{~m}$ & $133.0, \mathrm{CH}$ \\
\hline 15 & a: $2.35, \mathrm{~m} ; \mathrm{b}: 1.90, \mathrm{~m}$ & $39.7, \mathrm{CH}_{2}$ & $\mathrm{a}: 2.22, \mathrm{~m} ; \mathrm{b}: 1.87, \mathrm{~m}$ & $44.3, \mathrm{CH}_{2}$ \\
\hline 16 & $2.68, \mathrm{~m}$ & $33.3, \mathrm{CH}$ & $1.55, \mathrm{~m}$ & $42.6, \mathrm{CH}$ \\
\hline 17 & $6.06, \mathrm{~d}(9.9)$ & $155.7, \mathrm{CH}$ & $2.09, \mathrm{~d}(5.8)$ & $54.0, \mathrm{CH}$ \\
\hline 18 & & 131.6, C & & 147.7, C \\
\hline 19 & & 195.7, C & & 150.0, C \\
\hline 20 & & $204.8, \mathrm{C}$ & & 203.5, C \\
\hline 21 & a: $2.75, \mathrm{~m} ; \mathrm{b}: 1.94, \mathrm{~m}$ & $32.4, \mathrm{CH}_{2}$ & $2.23, \mathrm{~m}$ & $50.6, \mathrm{CH}$ \\
\hline 22 & a: $2.86, \mathrm{~m} ; \mathrm{b}: 1.63, \mathrm{~m}$ & $36.7, \mathrm{CH}_{2}$ & $\mathrm{a}: 3.20, \mathrm{~m} ; \mathrm{b}: 2.00, \mathrm{~m}$ & $44.0, \mathrm{CH}_{2}$ \\
\hline 23 & & 205.6, C & & 211.6, C \\
\hline 16-Me & $1.00, \mathrm{~d}(6.6)$ & $19.4, \mathrm{CH}_{3}$ & $0.97, \mathrm{~d}(6.8)$ & $21.8, \mathrm{CH}_{3}$ \\
\hline 18-Me & $1.86, \mathrm{~s}$ & $10.6, \mathrm{CH}_{3}$ & $1.96, \mathrm{~s}$ & $17.1, \mathrm{CH}_{3}$ \\
\hline $7-\mathrm{OH}$ & & & $4.62, \mathrm{~s}$ & \\
\hline 19-OH & & & $9.00, \mathrm{~s}$ & \\
\hline $3^{\prime}-\mathrm{OH}$ & & & $6.06, \mathrm{~s}$ & \\
\hline
\end{tabular}

To the best of our knowledge, only chaetoglobosin $Y$ and chaetoglobosin $Z$ [21] possess the same perhydro-isoindolone moiety as that of $\mathbf{1}$ among all known chaetoglobosins. However, their relative configurations at C-6 were different. Therefore, the absolute configuration of $\mathbf{1}$ was expected to be identical with that of chaetoglobosin $\mathrm{Y}$ or chaetoglobosin $\mathrm{Z}$. As a result, absolute conformational analyses of (3S, 4R, 5S, 6S, 8R, 9R, 16S)-1 and (3S, 4R, 5S, 6R, 8R, 9R, 16S)-1 were performed using time-dependent density functional theory (TDDFT)-ECD calculations. The results (Figure 4) indicated that the calculated ECD curve of $(3 S, 4 R, 5 S, 6 S, 8 R, 9 R, 16 S)$-1 matched well with the experimental one. In this way, the structure of $\mathbf{1}$ was elucidated (as shown in Figure 1) and named Chaetomadrasin A. 

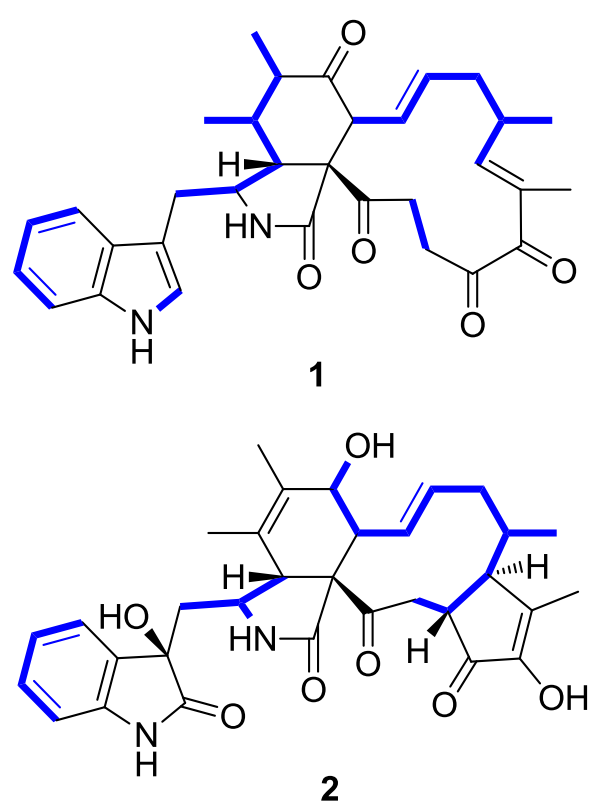

$-{ }^{1} \mathrm{H}-{ }^{1} \mathrm{H}$ COSY
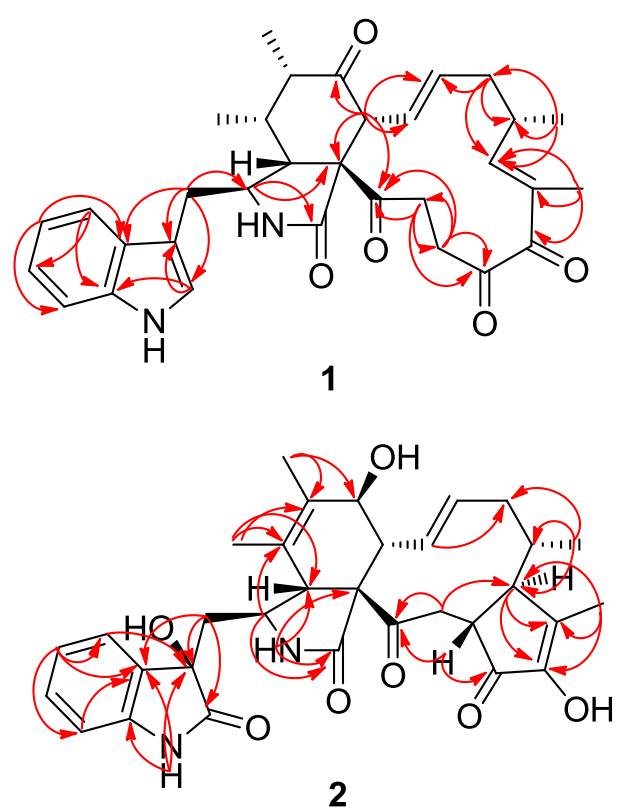

$\frown$ Key HMBC

Figure 2. ${ }^{1} \mathrm{H}-{ }^{1} \mathrm{H}$ COSY, Key HMBC of Compounds 1-2.
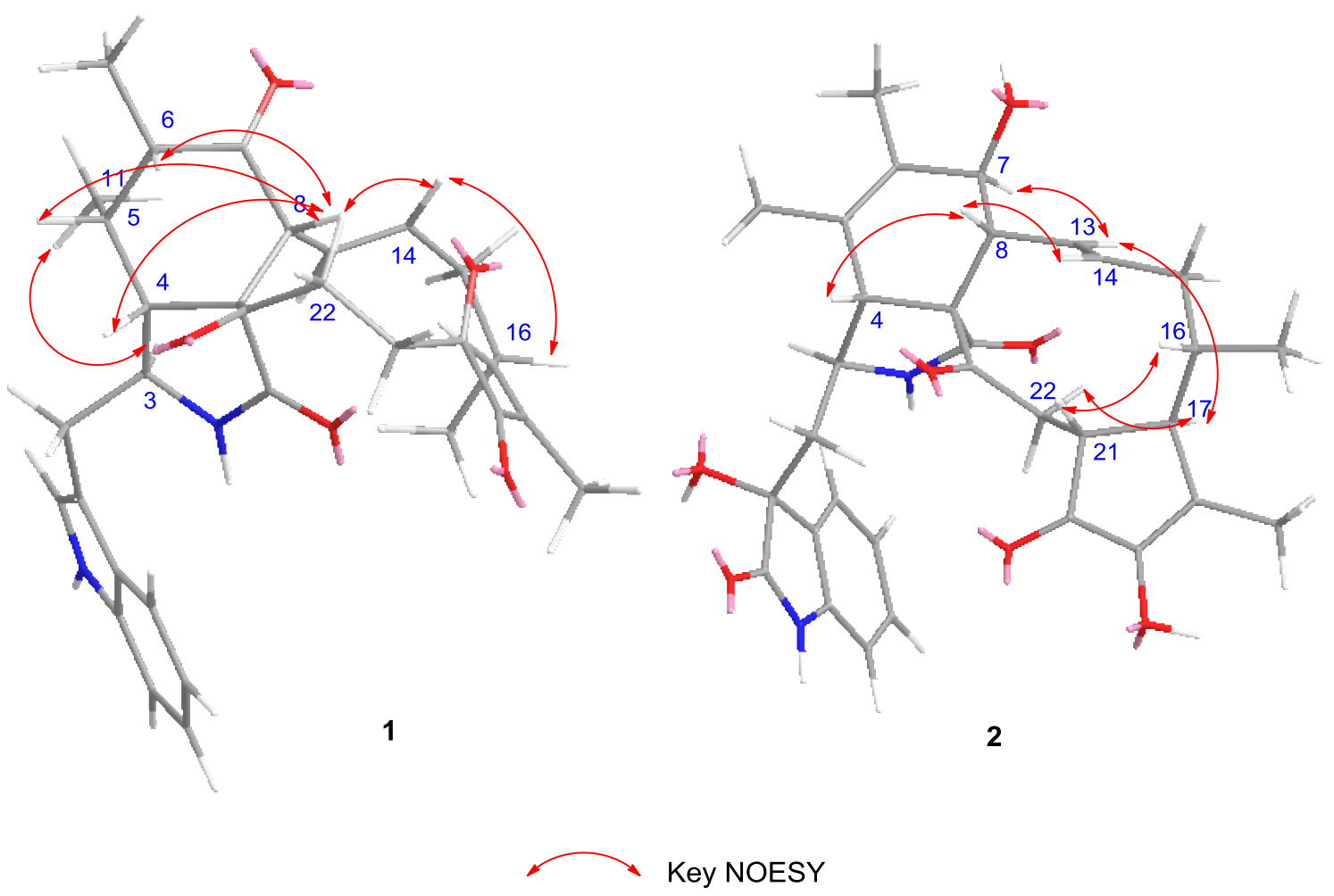

Figure 3. Key NOESY correlations of Compounds 1-2. 

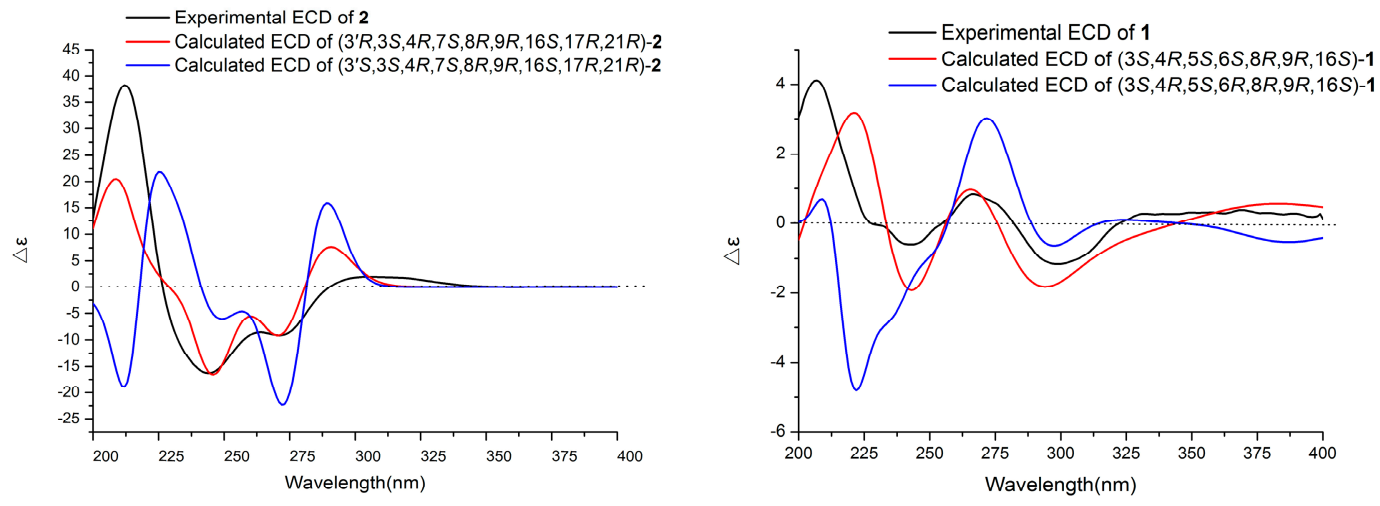

Figure 4. Experimental and calculated ECD spectra of Compounds 1 and 2.

Chaetomadrasin B (2) was also obtained as a white amorphous powder. The molecular formula of 2 was suggested to be $\mathrm{C}_{32} \mathrm{H}_{36} \mathrm{~N}_{2} \mathrm{O}_{7}$ on the basis of HR-ESI-MS $\left([\mathrm{M}+\mathrm{H}]^{+}\right.$at $\left.m / z 561.2590\right)$. Detailed analysis of the ${ }^{1} \mathrm{H}$ and ${ }^{13} \mathrm{C}$ NMR spectra (Table 1 ) of 2 indicated that this compound was also a chaetoglobosin derivative. The unexpected hydroxy and carbonyl groups fused to the indole ring in 2 were evidenced by the chemical shifts of $C-2^{\prime}\left(\delta_{C} 178.8\right)$ and $C-3^{\prime}\left(\delta_{C} 74.6\right)$, as well as the HMBC correlations from $\mathrm{H}-10$ to $\mathrm{C}-2^{\prime}, \mathrm{C}-3^{\prime}, \mathrm{H}-1^{\prime}$ to $\mathrm{C}-3^{\prime}, \mathrm{H}-3$ to $\mathrm{C}-3^{\prime}$ and $\mathrm{H}-4^{\prime}$ to $\mathrm{C}-3^{\prime}$ (Supplementary Figure S14). The complete structure of 2 was determined by correlative analysis of the 2D NMR spectra (Figure 3, Supplementary Figures S12-S14) and comparing the NMR data with chaetoglobosin $\mathrm{V}_{\mathrm{b}}$ (6) [22] and cytoglobosin A(7) [23]. The observed ROESY correlations (Figure 3, Figure S15) of $\mathrm{H}-3 / \mathrm{Me}-11 ; \mathrm{H}-7 / \mathrm{H}-13 ; \mathrm{H}-4 / \mathrm{H}-10 ; \mathrm{H}-8 / \mathrm{H}-14 ; \mathrm{H}-16 / \mathrm{H}-21 ; \mathrm{H}-13 / \mathrm{H}-17$ closely resembled those of chaetoglobosin $\mathrm{V}_{\mathrm{b}}(6)$, indicating the same relative configuration. The identical biosynthetic pathways, relative configurations, and similar ECD spectra (Figure 2) between 2 and chaetoglobosin $V_{b}(6)$ suggests that both compounds share absolute configurations, except for their indole ring moieties. Subsequently, the ECD experiments and ECD calculations (Figure 2) of 2 were applied to confirm the absolute configuration of C-3'. The absolute configuration of 2 was established as $\left(3^{\prime} R, 3 S, 4 R, 7 S\right.$, $8 R, 9 R, 16 S, 17 R, 21 R)-2$ by comparing its experimental and theoretical ECD spectra. Therefore, the structure of 2 was constructed as Chaetomadrasin B.

Six known cytochalasan alkaloids were identified as chaetoglobosin $G(3)[24,25]$, isochaetoglobosin $\mathrm{D}$ (4) [23], armochaetoglobin U (5) [26], chaetoglobosin $\mathrm{V}_{\mathrm{b}}$ (6) [22], cytoglobosin $A$ (7) [23], and cytoglobosin $A_{b}$ (8) [27] by comparing their NMR and HR-ESI-MS data with those in the scientific literature.

To make sure that $\mathbf{2}$ is not the reduction product of $\mathbf{1}$ during the experimental process, the crude extract was compared to that of pure compounds $\mathbf{1}$ and $\mathbf{2}$ via an HPLC chromatogram (see Figure S26). The result indicated that 1 and 2 are the products of $C$. madrasense 375. The cytotoxicity of 1 and 2 against the HepG-2 cell line were evaluated by using the Cell Counting Kit-8 (CCK-8) method. Compounds 1 and $\mathbf{2}$ showed moderate cytotoxicity against HepG2 human hepatocellular carcinoma cells with an $\mathrm{IC}_{50}$ of 8.7 and $19.4 \mu \mathrm{M}$, respectively. The $\mathrm{IC}_{50}$ value of the positive control (cis-platin) was $3.14 \mu \mathrm{M}$.

\section{Experimental Section}

\subsection{General Experimental Procedures}

Optical rotations were tested on a Perkin-Elmer 241 polarimeter (Waltham, MA, USA), UV data were recorded on a Hitachi U-4100 UV-Vis spectrophotometer (Hitachi co., Ltd, Tokyo, Japan), and the IR spectra $(\mathrm{KBr})$ were recorded on a Thermo Scientific NICOLET-iS5 FT-IR spectrometer (Thermo, San Jose, CA, USA). ECD spectra were acquired by a JASCO J-815 spectrometer (JASCO Corporation, Tokyo, Japan). NMR spectroscopic data were acquired in $\mathrm{CDCl}_{3}$ or DMSO- $d_{6}$ by using 
a Bruker AVANCE III 400 NMR spectrometer (Bruker, Billerica, MA, USA) with tetramethylsilane (TMS) or solvent signals $\left(\mathrm{CDCl}_{3} ; \delta_{\mathrm{H}} 7.26 / \delta_{\mathrm{C}} 77.0 ; \mathrm{DMSO}-d_{6} ; \delta_{\mathrm{H}} 2.50 / \delta_{\mathrm{C}} 40.0\right)$ as the internal reference. HR-ESI-MS were recorded on an Agilent 6250 TOF LC/MS (Agilent Technologies, Santa Clara, CA, USA). The semi-preparative HPLC was performed on a Calmflow ${ }^{\text {plus }}$ instrument packed with a YMC Pack ODS-A column $(10 \mathrm{~mm} \times 250 \mathrm{~mm} 5 \mu \mathrm{m}$, Japan) and a 50D UV-vis Detector (Lumiere Tech Ltd., Berlin, Germany). Column chromatography was carried on silica gel (200-300 mesh; Qingdao Marine Chemical Factory, Qingdao, China), reverse phase (ODS) silica gel (YMC, Tokyo, Japan), or Sephadex LH-20 (GE Healthcare BioSciences AB, Uppsala, Sweden). The chemicals used in the study were of analytical grade.

\subsection{Fungal Material}

The title fungus, strain number 375 (CCTCC M2019517 CLC375), was collected from a soil sample obtained in Hotan city, Sinkiang province, People's Republic of China. The strain was identified by Dr XueWei Wang as Chaetomium madrasense based on its morphological character, as well as the 18s rDNA sequence. The strain's sequences were deposited in the GenBank as KP269060.1. The strain was cultured on potato dextrose agar at $25^{\circ} \mathrm{C}$ for 7 days as the seed culture. Agar plugs were cut into small pieces (approximately $1 \mathrm{~cm} \times 1 \mathrm{~cm}$ ) and inoculated into 300 Erlenmeyer flasks ( $500 \mathrm{~mL}$ ), previously sterilized by autoclaving, each containing $60 \mathrm{~g}$ of rice and $100 \mathrm{~mL}$ of distilled water. All flasks were incubated at $25^{\circ} \mathrm{C}$ for 28 days.

\subsection{Extraction and Isolation}

After incubation, the fermented material was extracted by ethyl acetate ( 3 times) at room temperature, and the solvent was evaporated until it was dry under reduced pressure to produce a brown crude extract $(200.0 \mathrm{~g})$. The extract was fractionated by silica gel column chromatography eluted with $\mathrm{CH}_{2} \mathrm{Cl}_{2} / \mathrm{CH}_{3} \mathrm{OH}$ (100:0-1:1 v/v) to give six fractions (Fr.1-Fr.6). Fr. 4 (40.2 g) was subjected to silica gel column chromatography, eluted with petroleum ether/acetone (50:1-10:1 v/v) to give eight fractions (Fr. 4.1-Fr. 4.8). Fr. 4.5 (2.8 g) was further separated by Sephadex $\mathrm{LH}-20\left(\mathrm{CH}_{2} \mathrm{Cl}_{2} / \mathrm{MeOH}\right.$ v/v 1:1) to yield five subfractions (Fr.4.5.1-Fr.4.5.5). Fr.4.5.3 $(130 \mathrm{mg})$ was then purified by semipreparative HPLC (50\% MeCN in $\mathrm{H}_{2} \mathrm{O}$ ) to obtain chaetoglobosin $\mathrm{V}_{\mathrm{b}}\left(6 ; 39.5 \mathrm{mg}\right.$, $\left.t_{\mathrm{R}} 15.0 \mathrm{~min}\right)$. Fr.4.6 (6.5 g) was subjected to silica gel column chromatography and eluted with $\mathrm{CH}_{2} \mathrm{Cl}_{2} / \mathrm{MeOH}(50: 1-10: 1 \mathrm{v} / \mathrm{v})$ to get seven subfractions (Fr.4.6.1-Fr.4.6.7). Fr.4.6.2 (300 mg) was further separated by Sephadex LH-20 (MeOH) and semipreparative HPLC ( $50 \% \mathrm{MeCN}$ in $\mathrm{H}_{2} \mathrm{O}$ ) to obtain chaetoglobosin $\mathrm{G}\left(3 ; 16.5 \mathrm{mg}, t_{\mathrm{R}} 23.6 \mathrm{~min}\right)$. Fr.4.6.3 (1.12 g) was further separated by Sephadex LH-20 (100\% MeOH) and semipreparative HPLC (50\% MeCN in $\left.\mathrm{H}_{2} \mathrm{O}\right)$ to obtain Chaetomadrasin $\mathrm{A}\left(\mathbf{1} ; 8.6 \mathrm{mg}, t_{\mathrm{R}} 33.9 \mathrm{~min}\right)$ and isochaetoglobosin $\mathrm{D}(\mathbf{4} ; 4.5$ $\left.\mathrm{mg}, t_{\mathrm{R}} 22.9 \mathrm{~min}\right)$. Fr.4.6.4 (923 mg) was further purified by repeated silica gel column chromatography, Sephadex LH-20 chromatography $(\mathrm{MeOH})$, and semipreparative HPLC $\left(45 \% \mathrm{MeCN}\right.$ in $\left.\mathrm{H}_{2} \mathrm{O}\right)$ to obtain cytoglobosin A $\left(7 ; 2.0 \mathrm{mg}, t_{\mathrm{R}} 27.8 \mathrm{~min}\right)$. Fr.5 $(1.7 \mathrm{~g})$ was purified by silica gel column chromatography $\left(\mathrm{CH}_{2} \mathrm{Cl}_{2} / \mathrm{CH}_{3} \mathrm{OH}\right.$, v/v 10:1) and Sephadex LH-20 (100\% MeOH), followed by semipreparative (35\% $\mathrm{MeCN}$ in $\left.\mathrm{H}_{2} \mathrm{O}\right)$ to give cytoglobosin $\mathrm{A}_{\mathrm{b}}\left(8 ; 1.6 \mathrm{mg}, t_{\mathrm{R}} 37.5 \mathrm{~min}\right)$. Fr.6 (4.6 g) was subjected to ODS column eluted with $\mathrm{CH}_{3} \mathrm{OH} / \mathrm{H}_{2} \mathrm{O}(20 \%-100 \%$, v/v) to give 5 fractions (Fr. 6.1-Fr. 6.5). Fr.6.1 (500 mg) was further separated by Sephadex LH-20 (MeOH) and semipreparative HPLC $\left(45 \%\right.$ MeCN in $\left.\mathrm{H}_{2} \mathrm{O}\right)$ to obtain armochaetoglobin $\mathrm{U}\left(5 ; 3.5 \mathrm{mg}, t_{R} 27.0 \mathrm{~min}\right)$. Fr.6.2 $(802 \mathrm{mg})$ was further separated by Sephadex LH-20 (MeOH) and semipreparative HPLC $\left(30 \% \mathrm{MeCN}\right.$ in $\left.\mathrm{H}_{2} \mathrm{O}\right)$ to obtain chaetomadrasin $\mathrm{B}(2 ; 5.2$ $\left.\mathrm{mg}, t_{\mathrm{R}} 30.7 \mathrm{~min}\right)$.

Chaetomadrasin A (1): white amorphous powder; $[\alpha]^{25} \mathrm{D}=-8.5(\mathrm{c} 0.2, \mathrm{MeOH}) ; \mathrm{UV}(\mathrm{MeOH}) \lambda_{\max }$ (loge) 253(0.83), 221 (2.82), $216(2.81) \mathrm{nm}$; IR (KBr) $v_{\max } 3370,2926,1714,1458,746 \mathrm{~cm}^{-1}$; ECD(MeOH) $\lambda_{\max }\left(\Delta \varepsilon / \mathrm{M}^{-1} \mathrm{~cm}^{-1}\right)=298(-1.2), 267(+0.8), 243(-0.6), 207(+4.1) \mathrm{nm}$; for ${ }^{1} \mathrm{H}$ NMR, ${ }^{13} \mathrm{C}$ NMR, see Table 1; HR-ESI-MS m/z 551.2518 [M + Na] ${ }^{+}\left(\right.$calcd for $\mathrm{C}_{32} \mathrm{H}_{36} \mathrm{~N}_{2} \mathrm{O}_{5}, 551.2522[\mathrm{M}+\mathrm{Na}]^{+}$).

Chaetomadrasin B (2): white amorphous powder; $[\alpha]^{25} \mathrm{D}=-12.5$ (c $\left.0.2, \mathrm{MeOH}\right) ; \mathrm{UV}(\mathrm{MeOH})$ $\lambda_{\max }(\log \varepsilon) 254$ (2.68), 229 (3.22), 213 (3.08) nm; IR (KBr) $v_{\max }$ 3392, 3261, 2956, 1701, 1647,1470 cm $\mathrm{cm}^{-1}$; 
$\mathrm{ECD}(\mathrm{MeOH}) \lambda_{\max }(\Delta \varepsilon)=305(+2.0), 271(-9.2), 244(-16.3), 212(38.3) \mathrm{nm}$; for ${ }^{1} \mathrm{H}$ NMR, ${ }^{13} \mathrm{C}$ NMR, see Table 1; HR-ESI-MS $m / z 561.2590[\mathrm{M}+\mathrm{H}]^{+}\left(\right.$calcd for $\mathrm{C}_{32} \mathrm{H}_{36} \mathrm{~N}_{2} \mathrm{O}_{7}, 561.2523[\mathrm{M}+\mathrm{H}]^{+}$).

\subsection{Quantum-Chemical Calculation}

Monte Carlo conformational searches were run with the Spartan 10 software using the Merck Molecular Force Field (MMFF). The Selected conformers, which account for more than $1 \%$ of the Boltzmann distribution, were initially optimized at the B3LYP/6-31+G $(\mathrm{d}, \mathrm{p})$ level with the CPCM polarizable conductor calculation model in $\mathrm{MeOH}$. The conformers of 1 and 2 were calculated via ECD using the Time-dependent Density functional theory (TD-DFT) method at the B3LYP/6-31+G $(\mathrm{d}, \mathrm{p})$ level in $\mathrm{MeOH}$, and the rotational strengths of 30 excited states were calculated. ECD spectra were generated using the SpecDis 1.6 (University of Würzburg, Würzburg, Germany) and GraphPad Prism 5 (University of California San Diego, USA) software by applying Gaussian band shapes with sigma $=0.3 \mathrm{eV}$ from dipole-length rotational strengths [28].

\subsection{Bioactivity Assays}

\subsubsection{Cell Culture}

HepG2 (ATCC HB-8065) human hepatocellular carcinoma cells were cultured in a MEM (Minimum Essential Medium) growth medium with 10\% FBS (foetal bovine serum, TBD Science, Tianjin, China). Cells were cultured at $37^{\circ} \mathrm{C}$ with $5 \% \mathrm{CO}_{2}$.

\subsubsection{Cytotoxicity and Proliferation Assay}

Cell proliferation was determined by the Cell Counting Kit-8 (CCK-8) method. Cells were seeded in 96-well plates at a density of $2 \times 10^{5} \mathrm{cells} / \mathrm{mL}$ and cultured for $20 \mathrm{~h}$. Then, cells were treated with various concentrations of compounds or $1 \%$ DMSO (vehicle) in MEM supplemented with $10 \%$ FBS and cultured for $72 \mathrm{~h}$. cis-platin (DDP) (Sigma, St. Louis, MO, USA) was used for the positive control. Then, $10 \mu \mathrm{L}$ CCK-8 solution was added to each well and incubated for another $1 \mathrm{~h}$ at $37^{\circ} \mathrm{C}$ to convert WST-8 into formazan. Absorbance was monitored at $450 \mathrm{~nm}$ using a microplate reader. All experiments were repeated in triplicate, and the $\mathrm{IC}_{50}$ (concentration required to inhibit cell growth by $50 \%$ ) was determined using the Graphpad Prism 5 software (University of California San Diego, USA).

\section{Conclusions}

Two novel cytochalasan alkaloids, termed Chaetomadrasins A and B (1-2), together with six known analogues (3-8), were isolated from the soil-derived fungus, Chaetomium madrasense 375. Chaetomadrasins A (1) belongs to the chaetoglobosin family and characterized by the presence of all oxygen atoms in the form of Carbonyl for the first time. Chaetomadrasin B (2) represents the first example of chaetoglobosin type cytochalasan characterized by a hydroxy group and carbonyl group fused to the indole ring. The absolute configurations of compounds 1-2 were determined by extensive analysis of spectroscopic data and quantum chemical ECD calculations. Unfortunately, the antiproliferative activity of compounds $\mathbf{1}$ and $\mathbf{2}$ were evaluated against only HepG2 cell lines on base of small amount of the samples and showed moderate antiproliferative activity. In addition, further biological assays and structural diversity of cytochalasans are worth unveiling in future research.

Supplementary Materials: The following are available online. Figures S1-S18: HR-ESI-MS, IR, UV and NMR spectra of 1-2, Figures S19-S24 and Table S1-S8: ECD calculation details of compounds (1-2), Figure S25: 18S rDNA gene sequence of $C$. madrasense 375, Figure S26: HPLC chromatogram analysis of the crude extracts from $C$. madrasense 375 and pure compounds 1 and 2, Figures S27-S40: NMR spectra of compounds 3-8.

Author Contributions: Q.-F.G. and L.C. conceived and designed experiments and wrote the original draft. Q.-F.G., Z.-H.Y., and J.-J.Z. carried out the fungal culture, extraction, isolation, identification, and cytotoxicity testing of the compounds. W.-Y.K. and G.D. assisted with the structure elucidation and critically reviewed the manuscript. X.-W.W. and G.D. provided the fungal material and identified the fungus using ITS DNA analysis. 
Funding: This work was funded by the National Natural Science Foundation of China (31501552).

Acknowledgments: Authors thank Er-wei Li (Institute of Microbiology, Chinese Academy of Science, Beijing 100101, China) for spectral measurements.

Conflicts of Interest: The authors declare there is no competing financial interest.

\section{References}

1. Scherlach, K.; Boettger, D.; Remme, N.; Hertweck, C. The chemistry and biology of cytochalasans. Nat. Prod. Rep. 2010, 27, 869-886. [CrossRef]

2. Knudsen, P.B.; Hanna, B.; Ohl, S.; Sellner, L.; Zenz, T.; Döhner, H.; Stilgenbauer, S.; Larsen, T.O.; Lichter, P.; Seiffert, M. Chaetoglobosin A preferentially induces apoptosis in chronic lymphocytic leukemia cells by targeting the cytoskeleton. Leukemia 2014, 28, 1289-1298. [CrossRef]

3. Kumarihamy, M.; Ferreira, D.; Croom, J.E.M.; Sahu, R.; Tekwani, B.L.; Duke, S.O.; Khan, S.; Techen, N.; Nanayakkara, N.P.D. Antiplasmodial and cytotoxic cytochalasins from an endophytic fungus, Nemania sp. UM10M, isolated from a diseased Torreya taxifolia leaf. Molecules 2019, 24, 777. [CrossRef]

4. Zhang, J.; Ge, H.M.; Jiao, R.H.; Li, J.; Peng, H.; Wang, Y.R.; Wu, J.H.; Song, Y.C.; Tan, R.X. Cytotoxic chaetoglobosins from the endophyte Chaetomium globosum. Planta Med. 2010, 76, 1910-1914. [CrossRef]

5. Gao, W.X.; He, Y.; Li, F.; Chai, C.W.; Zhang, J.W.; Guo, J.R.; Chen, C.M.; Wang, J.P.; Zhu, H.C.; Hu, Z.X.; et al. Antibacterial activity against drug-resistant microbial pathogens of cytochalasan alkaloids from the arthropod-associated fungus Chaetomium globosum TW1-1. Bioorg. Chem. 2019, 83, 98-104. [CrossRef]

6. Li, H.; Xiao, J.; Gao, Y.Q.; Tang, J.J.; Zhang, A.L.; Gao, J.M. Chaetoglobosins from Chaetomium globosum, an endophytic fungus in Ginkgo biloba, and their phytotoxic and cytotoxic activities. J. Agric. Food Chem. 2014, 62, 3734-3741. [CrossRef]

7. Chen, C.M.; Zhu, H.C.; Wang, J.P.; Yang, J.; Li, X.N.; Wang, J.; Chen, K.L.; Wang, Y.Y.; Luo, Z.W.; Yao, G.M.; et al. Armochaetoglobins K-R, anti-HIV pyrrole-based cytochalasans from Chaetomium globosum TW1-1. Eur. J. Org. Chem. 2015, 2015, 3086-3094. [CrossRef]

8. Hua, C.Y.; Yang, Y.H.; Sun, L.; Dou, H.; Tan, R.X.; Hou, Y.Y. Chaetoglobosin F, a small molecule compound, possesses immunomodulatory properties on bone marrow-derived dendritic cells via TLR9 signaling pathway. Immunobiology 2013, 218, 292-302. [CrossRef]

9. Sun, L.; Hua, C.Y.; Yang, Y.H.; Dou, H.; Li, E.G.; Tan, R.X. Chaeoglobosin fex inhibits poly (I: C)-induced activation of bone marrow-derived dendritic cells. Mol. Immunol. 2012, 51, 150-158. [CrossRef]

10. Wang, H.H.; Li, G.; Qiao, Y.N.; Sun, Y.; Peng, X.P.; Lou, H.X. Chamiside A, a cytochalasan with a tricyclic core skeleton from the endophytic fungus Chaetomium nigricolor F5. Org. Lett. 2019, 21, 3319-3322. [CrossRef]

11. Zhu, H.C.; Chen, C.M.; Xue, Y.B.; Tong, Q.Y.; Li, X.N.; Chen, X.T.; Wang, J.P.; Yao, G.M.; Luo, Z.; Zhang, Y.H. Asperchalasine a, a cytochalasan dimer with an unprecedented decacyclic ring system, from Aspergillus flavipes. Angew. Chem. Int. Ed. 2015, 54, 13374-13378. [CrossRef]

12. Zhu, H.C.; Chen, C.M.; Tong, Q.Y.; Yang, J.; Wei, G.Z.; Xue, Y.B.; Wang, J.P.; Luo, Z.W.; Zhang, Y.H. Asperflavipine A: A cytochalasan heterotetramer uniquely defined by a highly complex tetradecacyclic ring system from Aspergillus flavipes QCS12. Angew. Chem. Int. Ed. 2017, 56, 5242-5246. [CrossRef]

13. Chen, C.M.; Zhu, H.C.; Li, X.N.; Yang, J.; Wang, J.P.; Li, G.T.; Li, Y.; Tong, Q.Y.; Yao, G.M.; Luo, Z.W.; et al. Armochaeglobines A and B, two new indole-based alkaloids from the arthropod-derived fungus Chaetomium globosum. Org. Lett. 2015, 17, 644-647. [CrossRef]

14. Zhang, D.W.; Tao, X.Y.; Liu, J.M.; Chen, R.D.; Zhang, M.; Li, L.; Fang, X.M.; Yu, L.Y.; Dai, J.G. Periconiasin G, a new cytochalasan with unprecedented $7 / 6 / 5$ tricyclic ring system from the endophytic fungus Periconia sp. Tetrahedron. Lett. 2016, 57, 796-799. [CrossRef]

15. Chen, L.; Liu, Y.T.; Song, B.; Zhang, H.W.; Ding, G.; Liu, X.Z.; Gu, Y.C.; Zou, Z.M. Stereochemical determination of new cytochalasans from the plant endophytic fungus Trichoderma gamsii. Fitoterapia 2014, 96, 115-122. [CrossRef]

16. Tan, X.M.; Li, L.Y.; Sun, L.Y.; Sun, B.D.; Niu, S.B.; Wang, M.H.; Zhang, X.Y.; Sun, W.S.; Zhang, G.S.; Deng, H.; et al. Spiciferone analogs from an endophytic fungus Phoma betae collected from desert plants in West China. J. Antibiot. 2018, 71, 613-617. [CrossRef] 
17. Zhang, X.Y.; Liu, Z.L.; Sun, B.D.; Niu, S.N.; Wang, M.H.; Tan, X.M.; Zou, Z.M.; Ding, G. Bioactive resorcylic acid lactones with different ring systems from desert plant endophytic fungus Chaetosphaeronema hispidulum. J. Agric. Food Chem. 2018, 66, 8976-8982. [CrossRef]

18. Song, B.; Li, L.Y.; Shang, H.; Liu, Y.; Yu, M.; Ding, G.; Zou, Z.M. Trematosphones A and B, two unique dimeric structures from the desert plant endophytic fungus Trematosphaeria terricola. Org. Lett. 2019, 21, 2139-2142. [CrossRef]

19. Li, L.Y.; Zhang, X.Y.; Tan, X.M.; Sun, B.D.; Wu, B.; Yu, M.; Zhang, T.; Zhang, Y.G.; Ding, G. Rhinoclactones A-E, resorcylic acid analogs from desert plant endophytic fungus Rhinocladiella simili. Molecules 2019, $24,1405$. [CrossRef]

20. Zheng, Q.C.; Kong, M.Z.; Zhao, Q.; Chen, G.D.; Tian, H.Y.; Li, X.X.; Guo, L.D.; Li, J.; Zheng, Y.Z.; Gao, H. Chaetoglobosin Y, a new cytochalasan from Chaetomium globosum. Fitoterapia 2014, 93, 126-131. [CrossRef]

21. Jiang, T.; Wang, M.H.; Li, L.; Si, J.G.; Song, B.; Zhou, C.; Yu, M.; Wang, X.W.; Zhang, Y.G.; Ding, G.; et al. Overexpression of the global regulator LaeA in Chaetomium globosum leads to the biosynthesis of chaetoglobosin Z. J. Nat. Prod. 2016, 79, 2487-2494. [CrossRef]

22. Xue, M.; Zhang, Q.; Gao, J.M.; Li, H.; Tian, J.M.; Pescitelli, G. Chaetoglobosin $\mathrm{V}_{\mathrm{b}}$ from endophytic chaetomium globosum: Absolute configuration of chaetoglobosins. Chirality 2012, 24, 668-674. [CrossRef]

23. Cui, C.M.; Li, X.M.; Li, C.S.; Proksch, P.; Wang, B.G. Cytoglobosins A-G, cytochalasans from a marine-derived endophytic fungus, Chatomium globosun QEN-14. J. Nat. Prod. 2010, 73, 729-733. [CrossRef]

24. Sekita, S.; Kunitoshi, Y.; Shinsaku, N. Chaetoglobosins, cytotoxic 10-(indol-3-yl)-[13]cytochalasans from Chaetomium spp. IV: ${ }^{13} \mathrm{C}$-nuclear magnetic resonance spectra and their application to a biosynthetic study. Chem. Pharm. Bull. 1983, 31, 490-498. [CrossRef]

25. Sekita, S.; Yoshihira, K.; Natori, S.; Kuwano, H. Chaetoglobosins, cytotoxic 10-(indol-3-yl)-[13]cytochalasans from Chaetomium spp. III. Structures of chaetoglobosins C, E, F, G, and J. Chem. Pharm. Bull. 1982, 30, 1629-1638. [CrossRef]

26. Chen, C.M.; Tong, Q.Y.; Zhu, H.C.; Tan, D.D.; Zhang, J.W.; Xue, Y.B.; Yao, G.M.; Luo, Z.W.; Wang, J.P.; Wang, Y.Y.; et al. Nine new cytochalasan alkaloids from Chaetomium globosum TW1-1 (Ascomycota, Sordariales). Sci. Rep. 2016, 6, 18711-18718. [CrossRef]

27. Wang, X.Y.; Yan, X.; Fang, M.J.; Wu, Z.; Wang, D.; Qiu, Y.K. Two new cytochalasan derivatives from Chaetomium globosum SNSHI-5, a fungus from extreme environment. Nat. Prod. Res. 2017, 31, 1669-1675. [CrossRef]

28. Liu, X.; Yang, J.; Yao, X.J.; Yang, X.; Fu, J.; Bai, L.P.; Liu, L.; Jiang, Z.H.; Zhu, G.Y. Linderalides A-D, Disesquiterpenoid-geranylbenzofuranone conjugates from Lindera aggregata. J. Org. Chem. 2019, 84, 8242-8247. [CrossRef]

Sample Availability: Samples of the compounds (1-8) are available from the authors.

(C) 2019 by the authors. Licensee MDPI, Basel, Switzerland. This article is an open access article distributed under the terms and conditions of the Creative Commons Attribution (CC BY) license (http://creativecommons.org/licenses/by/4.0/). 